\title{
Major Betty
}

Cite as: CMAJ 2019 March 25;191:E341-2. doi: 10.1503/cmaj.181033

CMAJ Podcasts: audio reading at https://soundcloud.com/cmajpodcasts/181033-enc

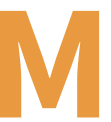
ajor Betty was dying. She presented to hospital with drowsiness and fever, which could have resulted from an easily treatable infection. When her blood grew Staphylococcus aureus, I knew she was in trouble. She had two prosthetic heart valves, fertile ground for S. aureus to stick and grow. Then I got the call from the cardiologist.

"This is an echo you need to see," she said.

The cardiologist's fellows gathered around as she showed them Betty's aortic root abscess from every angle. She amazed them with the Doppler, showing the flow into the space in the outflow tract, an incredible thing to see, but not to have.

An infection of a prosthetic valve would be incurable without surgery, and openheart surgery would be hard on any patient; for an 87-year-old woman with serious medical problems, such a surgery would be formidable.

When my medical team met her, Major Betty was beaming at us from her hospital bed, her son and granddaughter by her bedside. Although she was weak, her rosy cheeks and laugh lines made her look younger than her years. I explained what I knew.

"The problem is that Staph aureus is the stickiest bacteria of all and it's stuck to your heart valves. Even with antibiotics, it's hard to cure."

Betty sighed.

"I am a Christian," she said, a strong voice issuing from her frail frame. "I have been a Christian my entire life. I hope that some of you on my medical team are, too."

I smiled with trepidation and looked down at my name badge. I looked around at my team members. Ahmad. Orel. Hatim.

An awkward silence descended until, to my relief, my medical student, Danny, piped up.

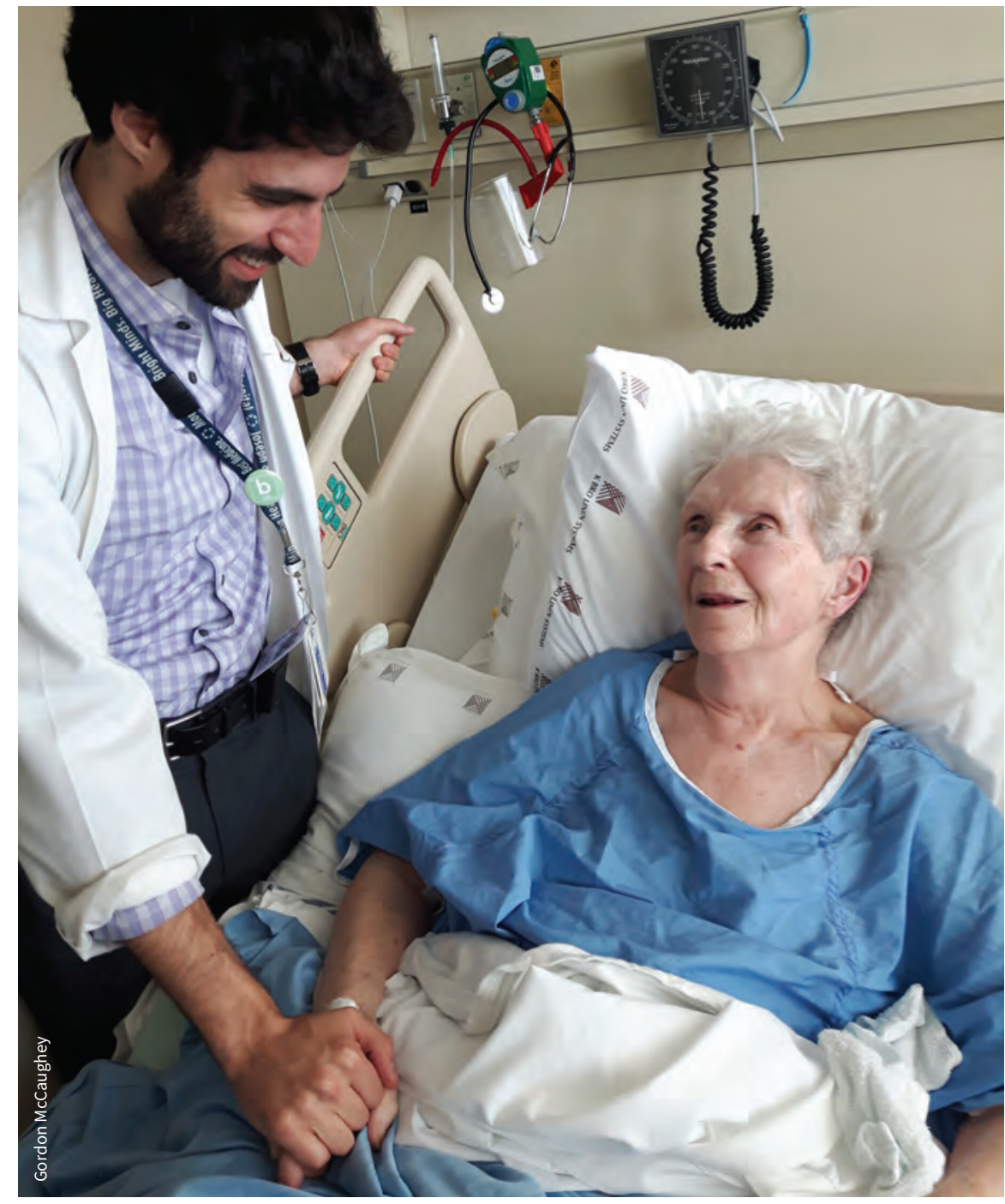

The author with Major Betty.

"Of course," he said, pulling a chain with a crucifix from his scrub top.

Betty's son, Gordon, stood up. He cleared his throat and adjusted his baseball cap.

"As a major in the Salvation Army, Betty has devoted her life to serving the poor and neglected," Gordon said. "She's done a lot of work for folks with addictions, even written a book about it."
"I didn't know there were majors in the Salvation Army!" I said.

"You don't need to salute me or anything," joked Betty, patting my hand.

"Betty," I began again. "Here's the hard part. With the bacteria stuck to your heart valve, you need surgery to replace it."

"Oh no," she said. "I don't want any more surgery." 
"Are you sure?" I asked. "Without it, there's no way to cure the infection."

"I don't want surgery," she repeated. "If the Lord deems it my time, then it's my time."

Her eyes shone. Her faith gave her a deeper understanding of her fate than a medical education would - she understood the finality of the diagnosis and that it didn't need to steal her vitality. But my awe at her conviction was tempered by my worry over her mortality. I hoped the antibiotics alone would be enough.

That night, I told my wife, Sarah, about my dying patient. I usually don't tell her about my cases, preferring to forget about work while at home, but I couldn't stop thinking about Betty's grace in the face of death. I felt as if Sarah and I could learn from her patience and poise; we had been trying to get pregnant for almost six months and were starting to get frustrated.

The next day, I went to see how Betty was doing.

"Are you Jewish?" she asked.

"Yes ..." I said, nervous about her motivation.

"Oh, that's wonderful," said Betty. Her granddaughter, Kimberley, and I smiled awkwardly at each other.

“'Ariel' means 'Lion of God' in Hebrew," I offered.

"Great name!" Kimberley exclaimed.

Gordon nodded approvingly, too.

"What a nice face," cooed Betty.

I blushed. "Betty, we should talk about your health."

Her mouth narrowed.

"Yes, I wanted to talk about these medicines," she said. "I don't want them anymore."

"The antibiotics? Are you sure?"

"My life is in the Lord's hands."

"But without the antibiotics, you'll die." My voice urged her to reconsider - I saw her certainty, but I could barely believe it. I had to be sure she understood the consequences of her decision.

Betty nodded deliberately, then looked up at the ceiling.

"'Ready to go, Lord, ready to stay, ready to serve Thy will. Ready for service, lowly or grand, ready my place to fill.'”

My jaw dropped. Eyes wide, I nodded. I knew she understood, perhaps more than any other patient I had ever seen in her position. I looked at Gordon and Kimberley for confirmation. They raised their eyebrows and nodded, too. They knew Major Betty.

We changed the focus of our care to relieving symptoms rather than treating her infection. I was glad we had discussed her wishes, because that afternoon, Betty became drowsy and delirious.

"She's been sleepy from the Ativan, but she still talks about you," Gordon told me the next morning.

I took Betty's hand and smiled at her. "I've been thinking of you, too, Betty. My wife is tired of me quoting you. She says 'Stop saying you're ready to go, Lord, ready to stay! Just stay, okay?'”

We all laughed.

"Did you see what we wrote on her board?"

I looked at the white board at the foot of Betty's bed. Her physician was listed as "Ariel, Lion of God."

I could feel a lump rising in my throat.

Kimberley showed me some old pictures of Betty in her Salvation Army uniform.

"These are amazing, Betty," I said.

Her eyes were closed, as if she might not have heard. Then she opened them and looked right at me. "You have ... a nice ... face."

"You're too much!" I scolded, laughing.

Gordon said, "Betty thought she was going to go yesterday, but she seems a bit brighter today. It's really up and down."

"It's hard to predict when someone will die, even for us doctors," I said.

"We don't say 'death,'” said Gordon. "In the Salvation Army, when someone dies, they are promoted to glory. They pass to their reward."

"It's no wonder Betty is so at peace," । said.

"The truth is, it's hard for us to be at peace, not knowing when it's going to happen," said Gordon.

I nodded.

"In Judaism, when we talk about life events, we say, b'sha'ah tovah: 'at the right time.' You can't speed things up that shouldn't be sped up. Death will come b'sha'ah tovah."

Gordon and Kimberley nodded. That seemed to resonate with them.

That evening, Sarah and I were still agonizing over last month's negative pregnancy test. The waiting felt interminable.
What if it never worked? I could feel the frustration and panic rising in both of us, but I tried to channel the calm of Major Betty. "B'sha'ah tovah, right?" I said.

On my last day on the medicine service, Major Betty was looking very close to death. Her breathing came in gasps, with long, quiet pauses in between.

"Betty wanted you to have these," Gordon said, handing me two books that Betty had written. "She dictated the inscriptions to you."

I turned them over in my hands.

One was a book on addictions, titled Living Life Alive. The other was about the founders of the Salvation Army. A gold chain hung between the pages, on which was inscribed the Serenity Prayer. I looked at it, then up at Gordon, with increasing alarm.

"That one has notes written in the margins," said Gordon. "It's Betty's copy."

"I can't take this!" I exclaimed. "I can't accept this."

"You must! She wanted you to have it. Gift-giving is very important to us."

Kimberley chimed in, "We each have our own copy. That one is yours now."

"I've been ... so moved by meeting you, Betty," I said, my voice quavering. "You're so inspiring, and ..."

Kimberley came over to me. "Let yourself go there. It's okay."

Betty passed to her reward that evening. She was surrounded by loving family. She was at peace.

Sarah was at the door when I got home.

"I'm the worst," she said, her eyes shining. "I should have waited to do it when you got home -"

"What? You checked? Is it positive?" I spluttered.

"We're pregnant!"

I was speechless, grinning and shaking.

"It's so early, probably just implanted," said Sarah, glowing. "I hope it sticks. I hope it's the stickiest."

\section{Ariel Lefkowitz MD}

General Internal Medicine, Sinai Health System - University Health Network and Sunnybrook Health Sciences Centre, Toronto, Ont.

This article has been peer reviewed.

This is a true story. Major Betty's family gave their consent for it to be told. 